Gazi Mühendislik Bilimleri Dergisi

2020, 6(2): 105-110

Araștırma Makalesi/Research Article

https://dergipark.org.tr/gmbd

\title{
Multifunctional and Low Cost Autonomous Mobile Robot
}

\author{
Ali Hakan IŞIK ${ }^{*}$ a $\left(\mathbb{0}\right.$, Ömer ÇETİN ${ }^{b}$ \\ ${ }^{a},{ }^{*}$ Burdur Mehmet Akif Ersoy Üniversitesi Bilgisayar Mühendisliği Bölümü, 15300, BURDUR, TÜRKIYE \\ ${ }^{b}$ Burdur Mehmet Akif Ersoy Üniversitesi Bilgisayar Mühendisliği Bölümü, 15300, BURDUR, TÜRKIYYE
}

\begin{tabular}{l} 
ARTICLE \\
INFO \\
\hline Received: 17.06 .2020 \\
Accepted: 14.08 .2020 \\
\hline Keywords: \\
Autonomous Robots, \\
Raspberry Pi, Arduino, \\
Low cost \\
"Corresponding \\
Authors \\
e-mail: \\
ahakan@ mehmetakif.e \\
du.tr
\end{tabular}

\begin{abstract}
With the development of micro controllers and single-board computer technologies, robotic systems can be designed at a lower cost. In this context, a low-cost autonomous mobile robot has been developed in presented study. By adding a variety of systems to the autonomous mobile robot, remotely controlled and steered robot was designed. In this study, Arduino and Raspberry cards were used for the autonomous mobile robot, which has a four-wheel and tracked structure. Using the Raspberry card and the Pi camera in the robot, the activities around the robot were transferred to the another computer via internet. A Wi-Fi (wireless fidelity) module was used to connect the internet. The Bluetooth module allows the camera to move right-to-left or up-to-down. The GPS (global positioning system) module has been utilized for the robot to act autonomously. With the ultrasonic distance sensor, the autonomous mobile robot can find a new route by overcoming obstacles. The battery can be charged with wireless charging without the need to be charged with a cable in case the battery weakens during movement. This robot can be used in cargo handling, patient assistance, food and beverage service, a relief vehicle in disaster situations. Designed low-cost autonomous mobile robot has distinguished features and presented development phases of robot can assist researchers.
\end{abstract}

\section{Çok Fonksiyonlu ve Düşük Maliyetli Otonom Mobil Robot}

\section{MAKALE BÍLGISİ \\ Alınma: 17.06.2020 Kabul: 14.08 .2020 \\ Anahtar Kelimeler: Otonom Robotlar, Raspberry Pi, Arduino, Düşük maliyetli \\ "Sorumlu Yazar: e-posta: ahakan@mehmetakif.e du.tr}

\section{öz}

Mikro denetleyicilerin ve tek kartlı bilgisayar teknolojilerinin gelișmesiyle robotik sistemler daha düşük maliyetle tasarlanabilmektedir. Bu bağlamda, sunulan çalışmada düşük maliyetli bir otonom mobil robot geliştirilmiştir. Otonom mobil robota çeşitli sistemler eklenerek uzaktan kumandalı ve yönlendirilen robot tasarlanmıştır. Bu çalışmada, dört tekerlekli ve paletli yapıya sahip otonom mobil robot için Arduino ve Raspberry kartları kullanılmıştır. Robotta bulunan Raspberry kart ve Pi kamera kullanılarak robotun etrafindaki aktiviteler internet üzerinden başka bir bilgisayara aktarılmıştır. İnternete bağlanmak için bir Wi-Fi (kablosuz uygunluk) modülü kullanılmıştır. Bluetooth modülü, kameranın sağdan sola veya yukarıdan aşağıya hareket etmesini sağlamaktadır. Robotun otonom hareket etmesi için GPS (küresel konumlandırma sistemi) modülü kullanılmıştır. Ultrasonik mesafe sensörü ile otonom mobil robot, engelleri aşarak yeni bir rota bulabilmektedir. Hareket sırasında bataryanın zayıflaması durumunda batarya bir kablo ile şarj edilmesine gerek kalmadan kablosuz şarj ile şarj edilebilmektedir. Bu robot, felaket durumlarında bir yardım aracı olan kargo hizmetlerine yardımda, hasta yardımı, yiyecek ve içecek hizmetlerinde kullanılabilir. Tasarlanan düşük maliyetli otonom mobil robot, ayırt edici özelliklere sahiptir ve robotun sunduğu geliştirme aşamaları araştırmacılara yardımcı olabilir.

https://dx.doi.org/10.30855/gmbd.2020.02.02

Bu makaleye atıf yapmak için: A. H. Işık and Ö. Çetin, "Multifunctional and Low Cost Autonomous Mobile Robot," Gazi Journal of Engineering Sciences, vol. 6, no. 2, pp. 105-110, August, 2020, doi: https://dx.doi.org/10.30855/gmbd.2020.02.02. 


\section{INTRODUCTION (GiRIŞs)}

Today's technology continues to develop rapidly. For example, important studies on cloud computing, new optimization methods, mobile applications and robot technologies are carried out [1-4]. Autonomous mobile robots are robots that can move from one location to another in order to perform simple or complex operations. It is used extensively in both indoor and outdoor security work, dangerous work or repetitive processes [5, 6]. It appears to have been used in military, hospital operations, agriculture, factories and many other areas [7-9].

The autonomous mobile robot study included in the article was developed by taking into account the human nature of sleep requirement, illness, distraction, psychological problems. Military personnel at the border lines of the countries keep watch for a long time and stay away from their family and children. Long-term seizures are inefficient seizures, but the cost of non- cheap causes problems. These problems cause staff to be affected socially or psychologically, and as a result, they wear out quickly. It is aimed to overcome this problem with a technological innovation.

In today's technology, robots can be designed using cost-effective or low-cost systems [10]. A low-cost autonomous mobile robot was designed in this article. An autonomous mobile robot with fixed four wheels and tracked was proposed. In order to control the mechanical part of the robot and enable it to operate in the form of an autonomous mobile robot, the Arduino Mega card, which is often used as a low-cost tutorial card, was utilized. Communication with the robot was enhanced using the Pi camera with the Raspberry Pi card, known as the Mini computer and easily supplied at a low cost. The Bluetooth module was used to increase the angle of view of the camera. The robot's ability to charge wirelessly made its charging easier. The main contributions of the proposed mobile robot is multi-functionality and lowcost. In the software part of the designed robot, $\mathrm{C}++$ programming language is used.

\section{HARDWARE DESIGN (DONANIM TASARIMI)}

\subsection{Mobile Robot Mechanical Structure (Mobil Robot Mekanik Yapist)}

The robot has a fixed frame with four wheels and a crawler structure. It is driven by two DC motors. In this way, the robot can move forward or backward. In order for the autonomous mobile robot to turn right or left, the motors are provided to move in opposite directions. The control scheme of the operation of the autonomous mobile robot with the Arduino Mega card is shown in Figure 1.

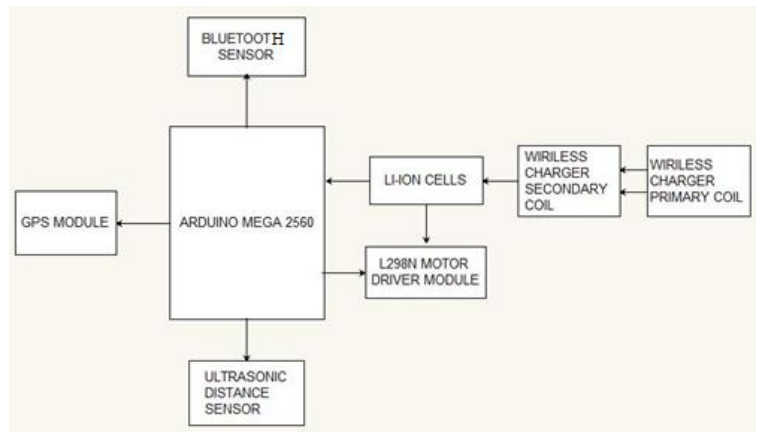

Figure 1. Autonomous mobile robot arduino card control scheme (Otonom mobil robot arduino kart kontrol şemasi)

A system design has been made that can move to the top of the robot so that the Pi camera on the robot can turn right/left or move up/down to increase the angle of view. An ultrasonic sensor was used to help the robot escape obstacles. The receiver and transmitter coils have been purchased ready for wireless charging.

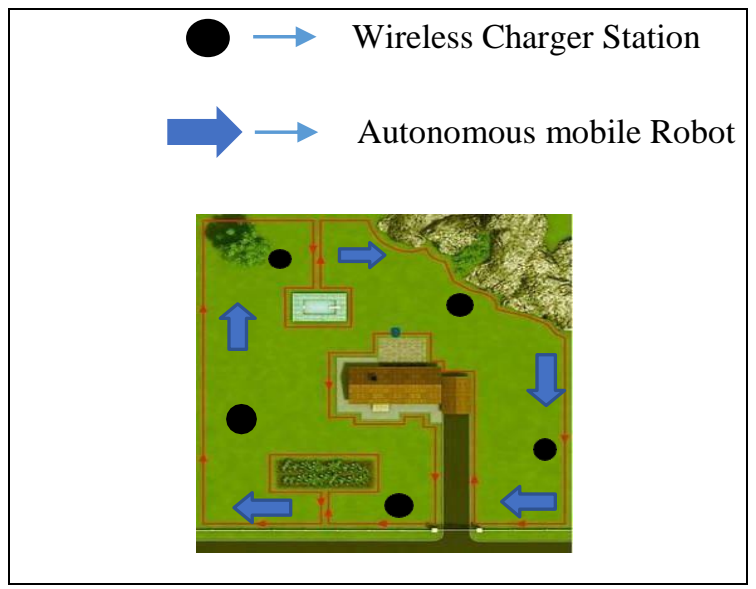

Figure 2. Layout of autonomous mobile robots and wireless chargers (Otonom mobil robotlarin ve kablosuz şarj cihazlarinin düzeni)

As shown in Figure 2, vehicle charging stations are placed at certain points provided they are hidden. The charging stations will allow the vehicle to charge without electrical contact. In the charging stations, a coil will be placed to create a magnetic field, and a coil that will induce voltage on this magnetic field will be placed in the vehicle. In addition, several autonomous mobile robot systems should be 
developed as a scenario. When a vehicle is charging, it must communicate with its deployment strategy and ensure that another vehicle continues to observe. In this way, uninterrupted data transfer to law enforcement units can be provided. Many robots are designed to roam in a swarm, but the difference is that the system can be charged with a wireless charger [11].

\subsection{Electronic Interface (Elektronik Arayüz)}

The Raspberry Pi and Arduino cards used for the mobile robot work separately. GPS systemis generally used for robot or vehicle tracking. Due to the low cost of some projects, a functional tracking system has been developed using Arduino card and GPS module together [12]. In this project, the GY-NEO6MV2 GPS module was used to enable the mobile robot to act autonomously. The latitude and longitude data from the GPS module and the latitude and longitude data entered when programming the Arduino Mega card are compared by the processor. Depending on the latitude and longitude difference, the L298N motor drives become active and the autonomous mobile robot begins to move forward/ backward or right/left. In the event of an obstacle, the ultrasonic sensor evades the obstacle and creates a new route.

The Pi camera on the Raspberry Pi card enables remote monitoring of events going on around the autonomous mobile robot via IP address [13]. To change the angle of the camera, the Arduino Mega card and the Bluetooth module were used. After mechanically adjusting the camera to move up/down or right/left, the L298N motor drives are activated after the data sent via Bluetooth is processed in the Arduino Mega so that the camera can take the desired angle.

The key features of the Raspberry Pi and Arduino Mega cards used are as follows. Technically 4 core 900 MHz ARMv7 Cortex processor in a Raspberry Pi ( $6 \mathrm{x}$ performance), 1 GB LPDDR2 SD RAM, 10/100 Ethernet RJ45 jack, 4 X USB2.0 Port, video/audio output: HDMI and 4-pole $3.5 \mathrm{~mm}$ connector, microSD card slot, 40 pin GPIO low cost minicomputer.

The Arduino Mega 2560 is an Arduino card containing an ATmega2560 microcontroller. 15 of the 54 digital / input outputs can be used as PWM outputs. In addition to these input and output, 16 analog inputs, 4 UART (hardware serial ports), one oscillator, 16 $\mathrm{MHz}$ crystal, a USB connection, a power jack (2.1 $\mathrm{mm})$, ICSP header, and a reset button. The Arduino Mega 2560 contains all the components needed by the microprocessor. The Arduino Mega 2560 is fed from a battery, adapter, power bank or USB port of the computer and runs easily.

The engines run from 3 to $6 \mathrm{~V}$, and at $5 \mathrm{~V}$, the DC motors consume about $100 \mathrm{~mA}$ to reach a speed of $200 \mathrm{rpm}$. Two servo motors are used to move the camera up/down or right/left. Four Li-ion batteries were used to enable the engines to move.

\section{SOFTWARE FEATURES APPLIED TO MOBILE ROBOT (MOBIL ROBOTA UYGULANAN YAZILIM ÖZELLIKLERI)}

\subsection{Image Transfer with Raspberry Pi Card (Raspberry Pi Kart ile Görüntü Aktarımı)}

The Raspberry Pi 2 card was used as the Raspberry Pi card. Because the Raspberry Pi 2 card does not have Wi-Fi capability, the Edimax EW-7811Un WIFI adapter has been equipped with WIFI capability. For easy control of the Raspberry Pi card, a 3.5' LCD screen was installed and connected.

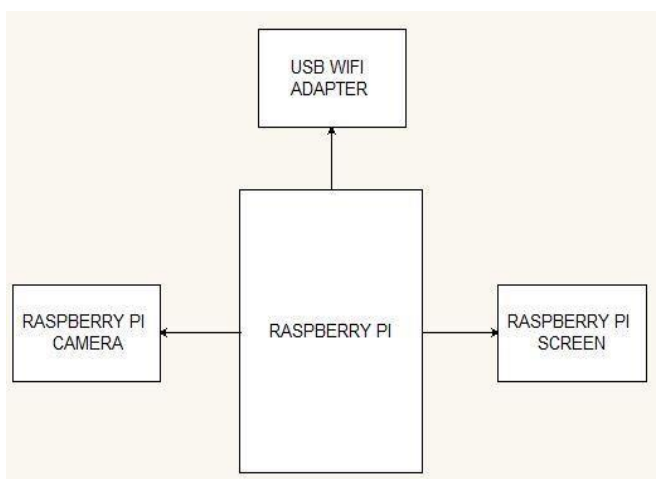

Figure 3. Raspberry Pi control scheme (Raspberry Pi kontrol şemasi)

The Raspberry Pi card was connected to the camera and the Raspberry Pi card enabled the camera and WIFI features. A VLC program was installed on a computer to check the operation of the camera. The camera was activated after the Internet connection to the Raspberry Pi card was made over WIFI. The IP address of Raspberry Pi card was entered into the VLC program and the image was transferred to the computer via IP address. It is now possible to save the video on the received computer.

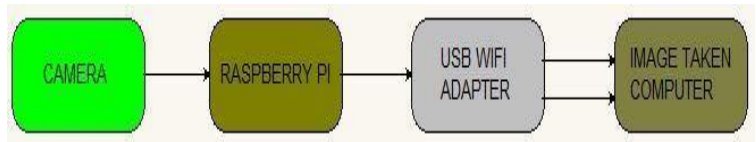

Figure 4. Image transfer system with raspberry $\mathrm{Pi}$ (Raspberry Pi ile görüntü aktarim sistemi) 


\subsection{Control Of Autonomous Mobile Robot With Arduino Card (Arduino Kartll Otonom Mobil Robotun Kontrolï)}

The Arduino Mega card was used in the autonomous mobile robot. The Arduino Mega card has a low cost and easy to control system. Because of these features, it is often preferred in many robotic applications.

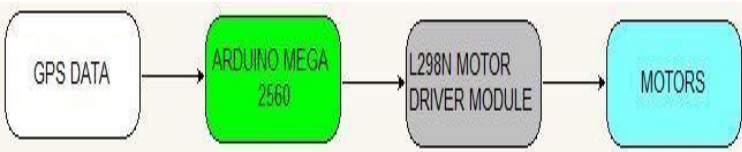

Figure 5. Engine control scheme with autonomous mobile robot GPS system (Otonom mobil robot GPS sistemi ile motor kontrol şemasi)

The GY-NEO6MV2 GPS module was used to enable the mobile robot to act autonomously. There is a margin of error of about 5 meters when it comes to location detection. In addition to determining the location, it also helps to determine the speed of the vehicle [14].

Connections were made and the GPS library was added to the Arduino Mega card. The coordinates of the desired destination of the autonomous mobile robot were entered into the software on the card. The coordinates from the GPS module and the coordinates inside the robot were compared to the Arduino Mega card. Depending on the data received, the engines were activated with the L298N motor drive, enabling the autonomous mobile robot to reach the desired position.

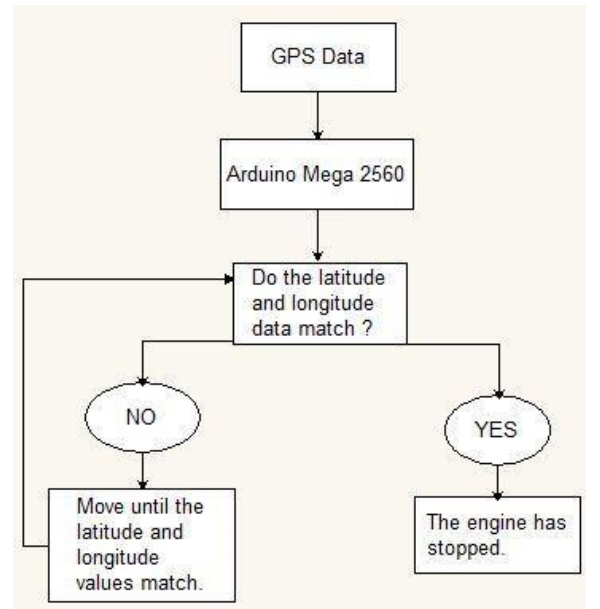

Figure 6. Autonomous mobile robot GPS operating system (Otonom mobil robot GPS işletim sistemi)
The engines were controlled by a Bluetooth module so that the camera of the autonomous robot, powered by wireless charging, could rotate 360 degrees and reach the desired height.

Connections of the Bluetooth module were made to the Arduino Mega card and Bluetooth software was added to the card. A phone with Bluetooth controlled the operation of the engines.

The HC-SR04 ultrasonic sensor was used as the distance sensor. The HC-SR04 ultrasonic sensor uses sound waves to identify obstacles facing it. It can see objects up to $2 \mathrm{~cm}$ and $400 \mathrm{~cm}$ away. The distance sensor was used in our project to avoid obstacles that could be encountered by the vehicle operating autonomously.

\subsection{Resonance System (Rezonans Sistemi)}

In the study, two coils were used, each in a selffrequency state. The transmitter coil, that is, the coil connected to the power source, emits a magnetic wave by oscillating at a certain frequency. The other coil resonates with the magnetic field, inducing a voltage on it. Thus, power transfer is provided.

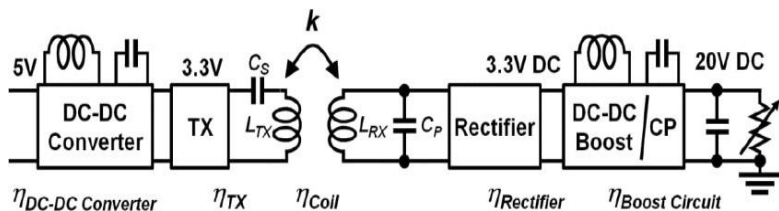

Figure 7. Resonance System (Rezonans Sistemi)

In the autonomous mobile robot study, a system like the one in Figure 7 was used. The winding numbers of the coils seen in the circuit vary according to the material we use and the battery in the circuit is determined depending on the capacity. As shown in Figure 7, a magnetic field was created between the coils and power was transferred.

\section{FINDINGS AND RECOMMENDATIONS (BULGULAR VE ÖNERILER)}

Especially low-cost mobile robot able to charge itself when it needs to be charged with becoming an autonomous robot that can be sent to the desired location adaptable to any terrain, in all environments the internet to be able to transfer images, and received images of the Raspberry Pi' e are the key benefits of the autonomous mobile robot that can be saved. The disadvantage of autonomous mobile robot is that the charging time is long because the

PRINT ISSN: 2149-4916 E-ISSN: 2149-9373 @ 2017 Gazi Akademik Yayıncllı 
autonomous mobile robot is charged with wireless charging, the computer where the image is transferred with Raspberry Pi must be connected to the same WIFI network and the image taken from Raspberry $\mathrm{Pi}$ is transferred to the computer approximately 13 seconds late. Recommended for autonomous mobile robot; person detection can be done by adding facial recognition feature to the camera system [15], attention should be paid to coil design and material used toincrease charging power [16], image transfer can be done in Internet-free environment using receiver and transmitter antenna.

Table 1. Unit price list of materials/services used in autonomous mobile robot (Otonom mobil robotta kullanilan malzeme / hizmetlerin birim fiyat listesi)

\begin{tabular}{|l|r|l|l|}
\hline Product Name & $\begin{array}{l}\text { Num } \\
\text { ber }\end{array}$ & Unit Price & Price \\
\hline Crawler Robot & 1 & $15 \$$ & $15 \$$ \\
\hline $\begin{array}{l}\text { GY-NEO6MV2 GPS } \\
\text { Module }\end{array}$ & 1 & $5 \$$ & $5 \$$ \\
\hline $\begin{array}{l}\text { Raspberry Pi Camera+ } \\
\text { Infrared LED Module }\end{array}$ & 1 & $15 \$$ & $15 \$$ \\
\hline $\begin{array}{l}\text { Raspberry Pi 3.5” } \\
\text { LCD Screen }\end{array}$ & 1 & $10 \$$ & $10 \$$ \\
\hline $\begin{array}{l}\text { Edimax Wireless USB } \\
\text { Adapter }\end{array}$ & 1 & $10 \$$ & $10 \$$ \\
\hline $\begin{array}{l}\text { 3.7V/2200mAh Li-Ion } \\
\text { Battery }\end{array}$ & 4 & $5 \$$ & $20 \$$ \\
\hline $\begin{array}{l}\text { 5V/2AWireless } \\
\text { Charger }\end{array}$ & 4 & $5 \$$ & $20 \$$ \\
\hline 5V DC Motor & 2 & $2 \$$ & $2 \$$ \\
\hline L298N Motor Driver & 2 & $1 \$$ & $2 \$$ \\
\hline $\begin{array}{l}\text { HC-06 Bluetooth } \\
\text { Module }\end{array}$ & 1 & $3 \$$ & $3 \$$ \\
\hline $\begin{array}{l}\text { HC-SR04 Distance } \\
\text { Sensor }\end{array}$ & 1 & $1 \$$ & $10 \$$ \\
\hline $\begin{array}{l}\text { Raspberry Pi 2 Model } \\
\text { B }\end{array}$ & 1 & $35 \$$ & $35 \$$ \\
\hline Arduino Mega 2560 & 1 & $10 \$$ & $10 \$$ \\
\hline TOTAL & $150 \$$ \\
\hline
\end{tabular}

\section{CONCLUSIONS (SONUÇLAR)}

In this study, a multi-functional, low-cost autonomous mobile robot system has been developed. With a fixed four-wheel and tracked structure, it is designed electronically with Raspberry $\mathrm{Pi}$ and Arduino Mega cards, an autonomous mobile robot system that can charge wirelessly. Basic design requirements for the development phase of autonomous mobile robot, low cost security robot creation, high quality terrain adaptation features are presented. The advantages of different mapping, avoiding obstacles, and being able to charge wirelessly were also studied. This autonomous mobile robot project could be a starting point for future research. Some possible investigations: cargo handling, patient assistance, food and beverage service, disaster situations may be a means of assistance.

\section{CONFLICT OF INTEREST STATEMENT (ÇIKAR ÇATIŞMASI BILLDIRIMI)}

The authors reported no potential conflict of interest.

\section{REFERENCES (KAYNAKLAR)}

[1] B. Ersever, İ. Doğru, and M. Dörterler, "Büyük Ölçekli Veri Merkezleri İçin Bulut Bilişim Kullanarak Sunucu Sanallaştırma," Gazi Mühendislik Bilimleri Dergisi (GMBD), cilt 3, say1 1, s. 20-26, Ocak, 2017.

[2] İ. Şahin, M. Dörterler, H. Gökçe, "Bozkurt Optimizasyon Yöntemi Kullanarak Basınç Yaylarının Minimum Hacme Göre Optimum Tasarımı," Gazi Mühendislik Bilimleri Dergisi (GMBD), cilt 3, say1 x s. 21-27, Haziran, 2017.

[3] İ. Doğru, O. Erdem, M. Akcayol, "Development of Reserved Reliable Flow Control Algorithm in Mobile Ad Hoc Networks," Gazi Mühendislik Bilimleri Dergisi (GMBD), cilt 4, say1 3, s. 144-156, Haziran, 2018, doi: 10.30855/GJES.2018.04.03.001.

[4] A. Karac1, and M. Erdemir, "Arduino ve Wifi Temelli Çok Sensörlü Robot Tasarımı ve Denetimi," Bilişim Teknolojileri Dergisi, cilt 10, say1 4, s. 435-449, Ekim, 2017, doi: 10.17671/gazibtd.307271.

[5] R. Siegwart and I. R. Nourbakhsh, Introduction to Autonomous mobile robots, USA: The MIT Press, 2004.

[6] L. Jaulin, Mobile robotics, USA: ISTE Press Elsevier, 2007.

[7] V. Tuğcu, N. C. Şener, S. Şahin, A. H. Yavuzsan, , F. G. Akbay, S. Apaydın, "Robot-assisted kidney transplantation: comparison of the first 40 cases of open vs robot-assisted transplantations by a single 
surgeon", BJU international, vol. 121, no. 2, pp. 275280, January, 2018, doi: 10.1111/bju.14014.

[8] A.Bechar, and C.Vigneault, "Agricultural robots for field operations. Part 2: Operations and systems," Biosystems engineering, vol. 153, no. 1, pp. 110-128, January, 2017, doi: 10.1016/j.biosystemseng.2016.11.004.

[9] A. W. K. To, G. Paul, and D. Liu, "A comprehensive approach to real-time fault diagnosis during automatic grit-blasting operation by autonomous industrial robots," Robotics and Computer-Integrated Manufacturing, vol. 49, no. 1, pp. 13-23, February, 2018, doi: 10.1016/j.rcim.2017.05.008.

[10] S. E. Oltean, "Mobile Robot Platform with Arduino Uno and Raspberry Pi for Autonomous Navigation," Procedia Manufacturing, vol. 32, no. 1, pp. 572-577, April, 2019, doi: 10.1016/j.promfg.2019.02.254.

[11] A. Kumar, S. Sharma, R. Tiwari, and S. Majumdar, "Area exploration by flocking of multi robot," Procedia Engineering, vol. 41, no. 1, pp. 377 382, February, 2012, doi: 10.1016/j.proeng.2012.07.187.

[12] A. Wirarespati, and Z. E. Rasjid, “Automotive Security with Authorization and Tracking via GPS," Procedia Computer Science, vol. 157, no. 1, pp. 72-78, October, 2019, doi: 10.1016/j.procs.2019.08.143.

[13] S. Prasad, P. Mahalakshmi, A. J. C. Sunder, R. Swathi, "Smart surveillance monitoring system using Raspberry Pi and PIR sensor," Int. J. Comput. Sci. Inf. Technol, vol. 5, no. 6, pp. 7107-7109, February, 2014.

[14] M. Sajjad, M. Nasir, F. U. M. Ullah, K. Muhammad, A. K. Sangaiah, and S. W. Baik, "Raspberry $\mathrm{Pi}$ assisted facial expression recognition framework for smart security in law-enforcement services," Information Sciences, vol. 479, no. 1, pp 416-431, January, 2019, doi: 10.1016/j.ins.2018.07.027.

[15] P. Machura, and Q. Li, "A critical review on wireless charging for electric vehicles," Renewable and Sustainable Energy Reviews, vol. 104, no. 1, pp. 209-234, April, 2019, doi: 10.1016/j.rser.2019.01.027

\section{Ali Hakan IŞIK}

Ali Hakan IŞIK graduated from Gazi University, Faculty of Engineering, Department of Electrical and Electronics Engineering in 2002. He worked as an engineer in private and public sectors. He started working at Gazi University in 2006. He attended Gazi University Institute of Science and Technology in 2005 and Master in 2012. He started working in Burdur Mehmet Akif Ersoy University, Faculty of Engineering and Architecture, Department of Computer Engineering, Department of Computer Science in 2013. In 2017, he received the title of Associate Professor in Computer Science and Engineering. He has articles on artificial intelligence, decision support systems, biomedical, software and optimization. Dr. Ali Hakan IŞIK is married and has two children.

\section{Ömer ÇETİN}

Ömer ÇETIN was born in Malatya, Turkey, on 18 January 1996. He graduated from the Energy Systems Engineering Department in Erciyes University, Kayseri, Turkey, in 2019. In 2019, he attended the MSc programme at the Computer Engineering Department in Burdur Mehmet Akif Ersoy University. His current fields of research are robotics coding, automation. 